DOI: $10.26693 / j m b s 06.03 .325$

UDC 616.62-003.7-074(651)

Beghalia Mohamed, Mendi Najet, Derri Lind

\title{
Search for Crystalline Species of Urinary Stones by Patients in the Region of Tissemsilt, Algeria
}

\author{
Ahmed Ben Yahia El Wancharissi University of Tissemsilt, Faculty sciences and technology, \\ Biology departement, Tissemsilt, Algeria
}

Urinary stones are among the most common diseases in the world and in Algeria as well, because it is a complex and multifactorial disease. The saturation of solutes in the urine is considered as the main stage of the deposition of crystals and their rapid growth and aggregation lead to the formation of stones in different places of the urinary system. It is the consequence of excessive urinary supersaturation causing renal complications such as lithiasis, nephrocalcinosis, acute or chronic renal failure which may progress to the terminal stage.

The purpose of the study was to identify the most common different forms of crystals in the urine of patients for further measures to prevent more serious complications of crystalluria.

Materials and methods. The study focused on all lithiasis patients of the age group "from 20 years to 84 years". Three-day urine samples were collected at different urology departments which were referred by urologists, during the period from February 06, 2020 to March 21, 2020. Being the best method, crystalluria was used to determine the types of crystals, their number and their growth. Three criteria must be met for the study of crystalluria to be clinically interpretable. They are the choice of patients according to their metabolic state; how long urine is stored after it is released, and the storage temperature.

Results and discussion. Thanks to this study it was possible to characterize many types of crystals, including calcium oxalates, in particular monohydrate, which is considered as a risk factor for stone formation. Also, the urinary acid crystals indicate a specific environmental pattern in many patients. In addition to the calcium phosphate crystals resulting from microbial infections, the results showed pure crystalline aggregates which will inevitably lead to lithiasis. The microscopic examination of patient urine samples is the preferred method for optimal patient assurance with the cooperation of therapists and doctors in addition to the epidemiological study.

Conclusion. The relatively high rate of recurrent lithiasis illustrates the current limits of preventive mea- sures which can be penalized by the lack of patient attendance but whose reduced effectiveness primarily suggests a lack of knowledge of one or more fundamental determinants of the lithogenic process. The experimental part showed a diversity of crystals in the urine of patients, pure calcium oxalate monohydrate, which was noticed in the majority of the subjects analyzed. The detection, in crystalluria, of a single crystal of whewellite can therefore be considered as a marker for hyperoxaluria. Weddellite was more common in the urine of subjects under analysis.

Keywords: crystals, urolithiasis, crystalluria, crystalline aggregation, urinary tract.

Introduction. Crystalluria refers to the presence of crystals in the urine. It is the consequence of excessive urinary supersaturation causing renal complications such as lithiasis, nephrocalcinosis, acute or chronic renal failure which may progress to the terminal stage. However, crystalluria in itself is not a pathological marker. The distinction between a "physiological" crystalluria and a "pathological" crystalluria is due to the recognition of the different criteria which characterize it: $\mathrm{pH}$ of the urine, nature of the crystals, crystalline facies, abundance, aggregation, but also frequency of crystalluria appreciated by the repetition of the examination on serial samples [1]. A large number of people around the world suffer from urolithiasis disease, which is expressed by the formation of stones in the kidney or urinary tract (calyxes, ureters, bladder, urethra) [2]. The calculation is an agglomeration of crystals linked by an organic matrix [3]. It is a multifactorial pathology that arises from very diverse causes: changes in nutritional habits, sanitary conditions, environmental factors, the prevalence of conditions which predispose to the risk of lithiasis [4], urinary infections, drugs, anatomical malformations of the urinary system, or constitutional or acquired metabolic pathologies [5]. Urolithiasis affects from 4 to $20 \%$ of the population depending on the country [6]. Lithogenesis involves several phases which are expressed successively or simultaneously. Certain 
stages, which concern the first phases of lithogenesis and which can be referred to as "crystallogenesis", correspond to the formation of crystals from substances initially dissolved in the urine and do not constitute a pathological process in themselves. It is, in fact, well known that crystallization is observed in many normal urine, reflecting the state of supersaturating of these vis-à-vis several urinary solutions such as calcium oxalate, uric acid or calcium phosphate [7]. The main pathophysiological mechanisms of the most frequent types of kidney stones and who and how to conduct the metabolic research are briefly described. Medical treatment is also addressed, keeping in mind that nephrolithiasis is often accompanied by extra-renal manifestations that should be investigated and treated, namely arterial hypertension, obesity, diabetes mellitus and osteo-metabolic disease [8]. Crystallization in urine is a complex process depending not only on the concentration of stone forming ions but also on chelators like citrate or magnesium which reduce free ionic concentration of calcium and oxalate and on ionic strength diminishing the chemical activity of ions [9]. Clinical and experimental investigation shows that calcium and oxalate afflux to urine and diuresis are important factors for calcium stone formation. Kidney calcifications being an important source of stones are a frequent finding even without stone disease. Calcium oxalate crystals too often are observed in urine[10]. Mechanism of stone formation is a complex process which results from several physicochemical events including supersaturating, nucleation, growth, aggregation, and retention of urinary stone constituents within tubular cells. These steps are modulated by an imbalance between factors that promote or inhibit urinary crystallization. It is also noted that cellular injury promotes retention of particles on renal papillary surfaces. The exposure of renal epithelial cells to oxalate causes a signaling cascade which leads to apoptosis by p38 mitogen-activated protein kinase pathways [11].

The purpose of the study. In the present work, we have analyzed the urine of lithiasis patients to determine the different types of crystals.

Materials and methods. The study focused on all lithiasis patients of the age group "from 20 years to 84 years". We collected three-day urine samples at different urology departments which were referred by urologists, during the period from February 06, 2020 to March 21, 2020.

All experiments were conducted in accordance with the Council of Europe Convention "On the Protection of Human Rights and Dignity of the Human Being with regard to the Application of Biology and Medicine Application of Biological and Medicine Achievements (ETS No. 164)" dated 04.04.1997, and the Helsinki Declaration of the World Medical Association (2008).

The circuit for patients with lithiasis has been established: care path for lithiasis patients. First, the interview data is collected: age, sex, personal history, family history of lithiasis, then the clinical examination data: weight, height, body mass index, and the results of the biological assessment. The urine dipstick examination is then performed on fresh urine upon awakening, and the urine $\mathrm{pH}$ is measured. Finally, there is the study of crystalluria. All of this data is collected in an exploitation sheet.

In current practice, three criteria must be met for the study of crystalluria to be clinically interpretable:

- The first criterion is the choice of direct debit. This should essentially reflect the metabolic state of the patient without underestimating the influence of diet (especially in patients with lithiasis), but this should have a limited impact [12].

- The second criterion is how long urine is stored after it is released. Ideally, urine should be issued to the laboratory and examined without delay, but these technical constraints make it difficult to perform this examination on a daily basis. Studies of urine storage at room temperature or at $37^{\circ} \mathrm{C}$ have shown that if the sample was stored less than 3 hours after emission (above $20^{\circ} \mathrm{C}$ ), the evolution of crystalluria was weak and the results could be interpreted in the same way as those obtained on freshly emitted urine [13].

- The third criterion is the storage temperature. The more the temperature drops, the more the propensity for crystal formation increases. This results in a higher frequency of crystalluria, but also in a greater number of crystals formed. The urine stored at $+4^{\circ} \mathrm{C}$ is of little or no interest for a first-line crystalluria study. The urine after storage at $4^{\circ} \mathrm{C}$ for 48 hours, is used to look for any deposits and to confirm the presence of crystals observed in urine to rise [12].

Preparation of the centrifugation pellet included several stages:

- the urine is gently homogenized;

- immediately pour into a conical tube; filling it to $3 / 4$.

- centrifuge for 5 minutes at medium speed;

- the supernatant urine is discarded;

- shake the tube to resuspend the pellet;

- we aspirate a few drops of the base with a pipette;

- place a drop on a slide and cover with a coverslip [14].

Polarization microscope examination. The counting cell placed under the optical microscope allows a qualitative and quantitative study of cytology (red blood cells, leukocytes, bacteria, yeasts, etc.) and crystalluria. The search for crystals is usually done at magnification $(\times 40)$. When there are few crystals, it is necessary to search for them by sweeping the entire 
blade. The search for crystals and aggregates also requires examining the entire slide [15].

Research results. Various pure or mixed crystalline species (associated) can be distinguished in the urine of lithiasis patients which are shown in Figures 1-9.

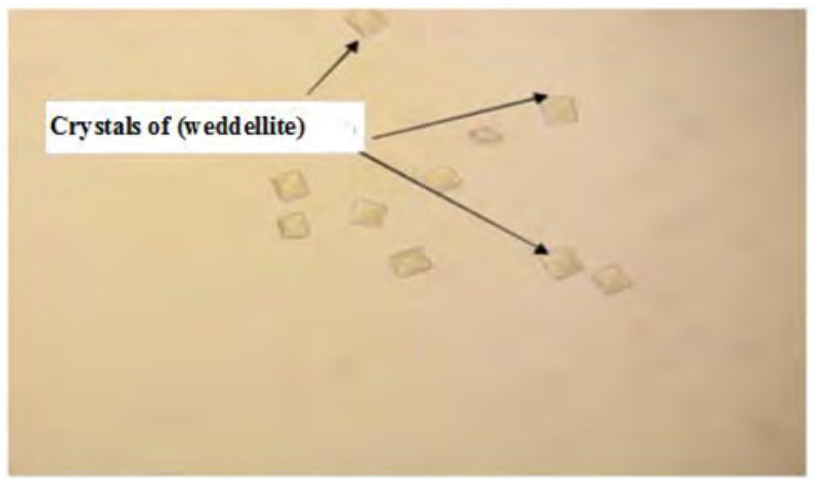

Figure 1. Dihydrated calcium oxalate (weddellite) / pure crystals. $\times 40$

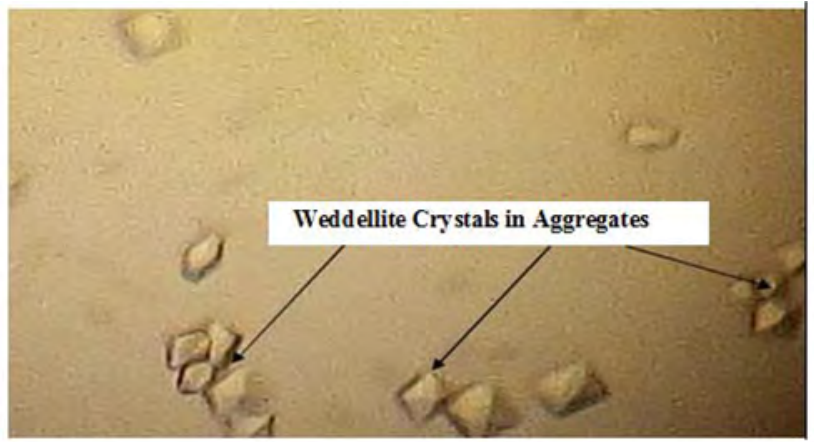

Figure 2. Weddellite Crystals in Aggregate (Calcium Oxalate Dihydrate). $\times 40$

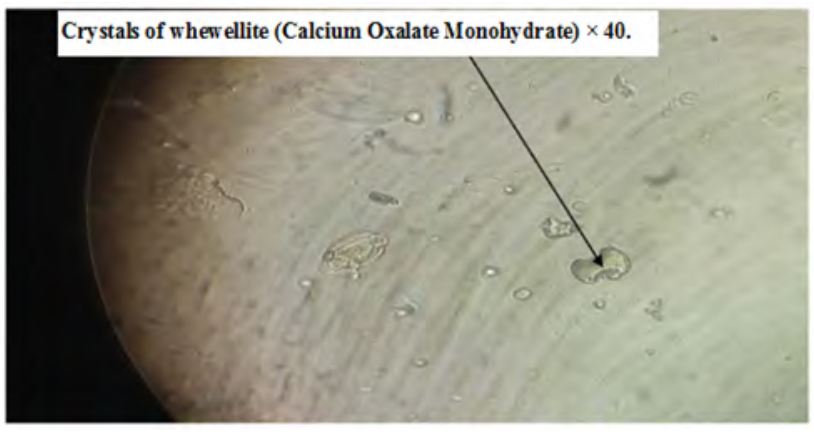

Figure 3. Crystals of whewellite (Calcium Oxalate Monohydrate).$\times 40$

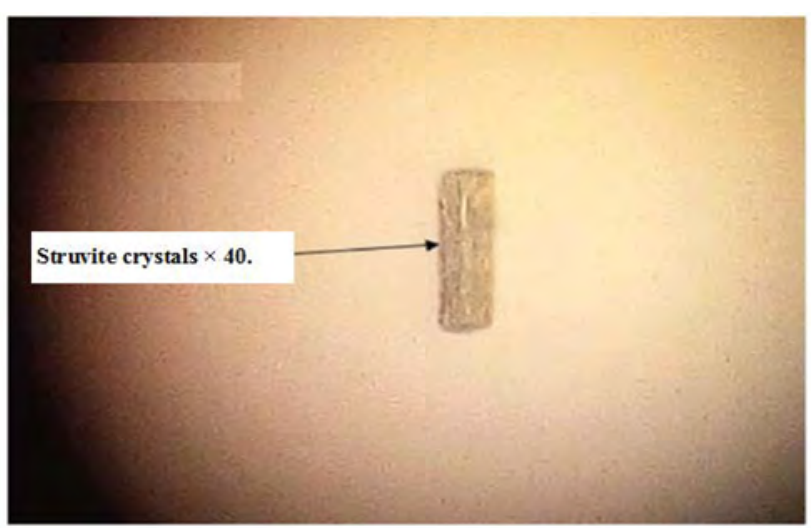

Figure 4 . Struvite crystals. $\times 40$

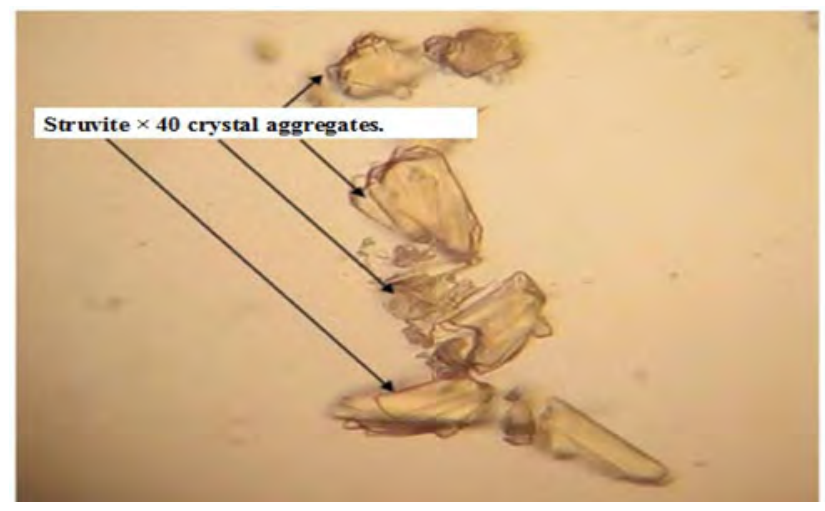

Figure 5. Struvite $\times 40$ crystal aggregates

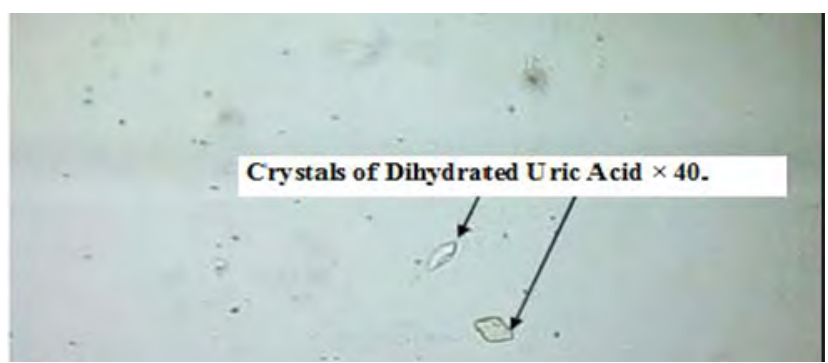

Figure 6. Crystals of Dihydrated Uric Acid. $\times 40$

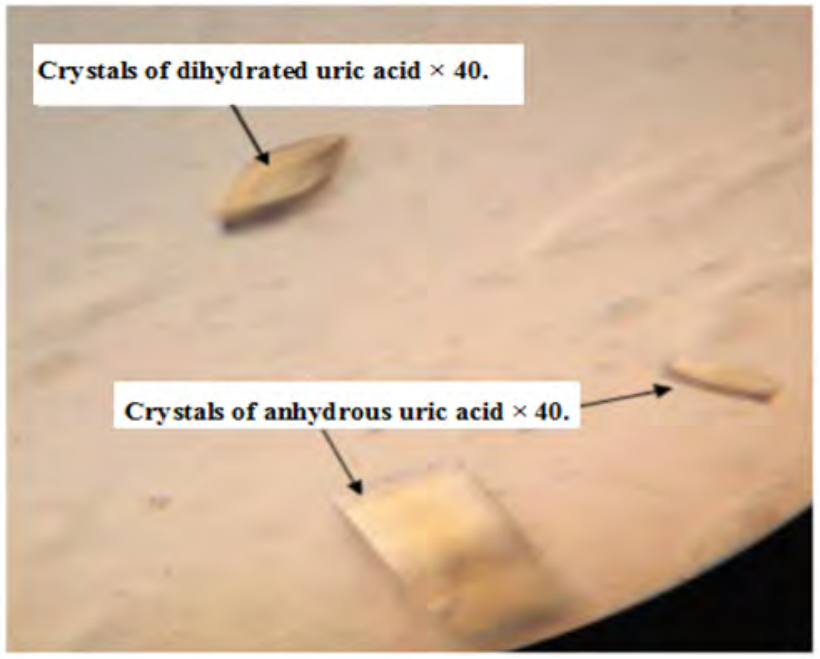

Figure 7. Crystals of dihydrated and anhydrous uric acid. $\times 40$

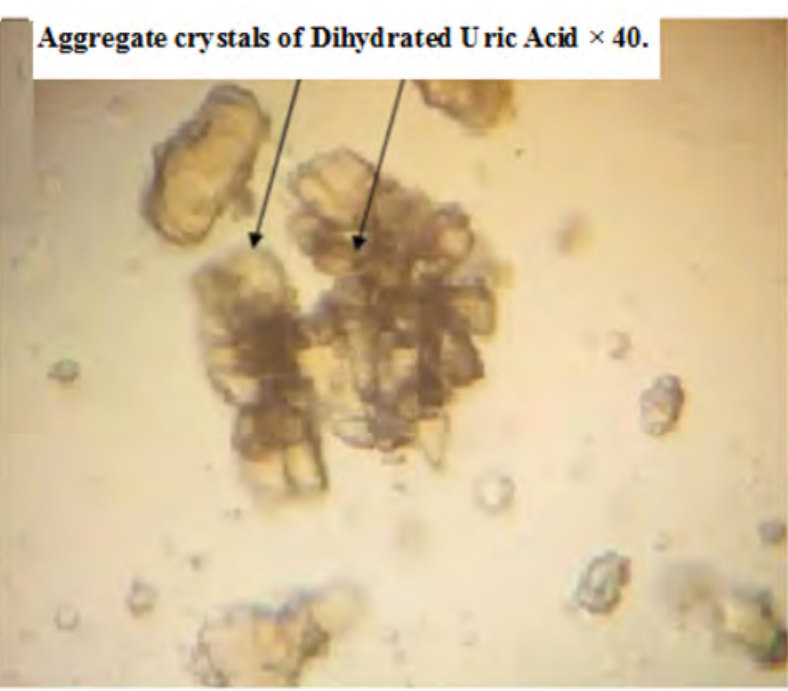

Figure 8. Aggregate crystals of Dihydrated Uric Acid.

$$
\times 40
$$




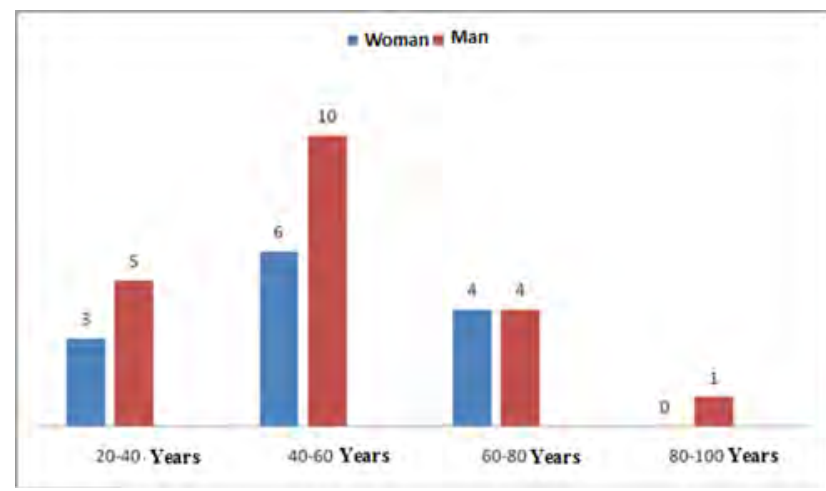

Figure 9. Distribution of the sample according to the age group and sex of the patient

patients according to the model shown in the appendix. The microscopic analysis of the urine was carried out using the protocol cited in the working method. The average sex ratio represents 1.54 with a mean age of $84 \pm 20$ years old. The most affected age group is the 40-60 age group with a predominance of men as expressed in Figure 9.

Crystalluria was more common in the 40-60 age group, depending on the sex and age of the patients as shown in Figure 9. Calcium oxalate was the most common component, shared between whewellite and weddellite $(40.42 \%)$. It was classified after uric acid in its two most common forms $(46.80 \%)$, and finally calcium phosphates with (12.66\%) (Table 1). In humans uric acid was by far the predominant crystalline species $(27.64 \%)$, followed by calcium oxalate $(19.14 \%)$ and then by calcium phosphates $(6.38 \%)$. In the two sexes, there was no significant difference in the distribution of crystal species according to the age of the patients (Table 2).

Table 1 - Pure and mixed crystal species in lithiasis patients

\begin{tabular}{|c|c|c|c|}
\hline \multicolumn{1}{|c|}{ Constituant } & $\begin{array}{c}\text { Pure } \\
\text { crystals }\end{array}$ & $\begin{array}{c}\text { Mixted } \\
\text { crystals }\end{array}$ & $\begin{array}{c}\text { Total } \\
\text { (crystals) }\end{array}$ \\
\hline $\begin{array}{c}\text { Calcium oxalate, } \\
\text { including: }\end{array}$ & & & \\
Whewellite & 4 & 4 & 8 \\
Weddellit & 4 & 7 & $\begin{array}{c}11 \\
\mathbf{1 0 / 4 2} \%\end{array}$ \\
\hline $\begin{array}{c}\text { Calcium } \\
\text { phosphate, } \\
\text { including: }\end{array}$ & & & \\
Phosphate & 2 & 1 & 3 \\
Brushite & 00 & 1 & 1 \\
Struvite & 1 & 1 & 2 \\
\hline Uric acid & 13 & 9 & 22 \\
\hline
\end{tabular}

Table 2 - Crystal species by sex in lithiasis patients

\begin{tabular}{|c|c|c|c|}
\hline Majority constituents & $\begin{array}{c}\text { Men } \\
(\mathbf{n = 2 0})\end{array}$ & $\begin{array}{c}\text { Women } \\
(\mathbf{n}=\mathbf{1 3})\end{array}$ & $\begin{array}{c}\text { Totaln } \\
(\mathbf{n}=\mathbf{3 3})\end{array}$ \\
\hline Whewellite & 2 & 6 & 8 \\
Weddelite & 7 & 4 & 11 \\
\hline & $19.14 \%$ & $21.27 \%$ & \\
\hline $\begin{array}{c}\text { Calcium phosphate } \\
\text { dcalcium }\end{array}$ & & & \\
\hline $\begin{array}{c}\text { Phosphate amorphe } \\
\text { Brushite }\end{array}$ & 1 & 2 & 3 \\
Struvite & 1 & 0 & 1 \\
& $19.14 \%$ & $21 / 27 \%$ & 2 \\
\hline & 13 & 9 & 22 \\
\hline
\end{tabular}

The crystalline species in the urine of lithiasis Calcium oxalate

A study carried out on more than 7000 urines showed that crystalluria consisted, in $50 \%$ of cases, of two crystalline species where calcium oxalate is the most frequent species, of which weddellite constitutes $33 \%$ and whewellite $8 \%$ [16].

In our work, the comparison of the nature of the chemical and crystalline species is presented by calcium oxalate dihydrate (weddellite or $\mathrm{C} 2$ ) in different size, and in bulky aggregates (Figure 1, 2). These results show that calcium oxalate dominated among all patients consulted by his urine samples, reflected nutritional habits and health conditions, environmental factors. Oxalate is the molecule which, by combining with calcium, gives rise to the majority of kidney stones. Part of the oxalate is endogenous, that is to say manufactured by our body, another part comes from our diet. Cocoa and therefore dark chocolate are among the food richest in oxalate. It is also found, but in smaller quantities, in tea, spinach, chard, sorrel, broccoli, peanuts, almonds, rhubarb, pepper, beetroot, sweet potato, dried figs, peanuts, nuts (hazelnuts, mahogany) and their butters. Unfortunately, no more details can be reported regarding the count of these crystals given the situation we have reported. Regarding the large sizes of weddellite and the formation of aggregates is a sign of risk that requires the management of its patients who are in the process of forming lithiasis urinary. The formation of calcium oxalate stones goes through four phases: a nucleation phase, a growth phase, an aggregation phase and a retention phase. Stone formation is a complex and multifactorial phenomenon which involves proteins, among other factors [17].

The second type of calcium oxalate is monohydrate (whewellite or $\mathrm{C} 1$ ) presented in Fig. 3 . The presence of whewellite in urine can therefore be considered as an indicator of an oxalo-dependent calculus, predominant in whewellite, whose resistance to modern urological lithotripsy treatments is often greater than that of weddellite stones, which may lead to 
considering a particular stone treatment strategy [18]. This explains the inconstant presence of whewellite in crystalluria. However, the relatively high frequency $(23.1 \%)$ with which whewellite has been detected in the urine of people with gallstones suggests that hyperoxaluria plays an important role in stone formation. It is remarkable that the mere presence of whewellite crystals in the urine was strongly correlated with the dominant presence of whewellite in the stones. Indeed, of the 18 patients whose urine contained whewellite crystals, 16 or $88.9 \%$ had a predominantly whewellite stone. This form of lithiasis is frequent in Algeria as evidenced by the results of a recently published study showing that $48 \%$ of stones observed in western Algeria were predominantly in whewellite [19]. The frequencies that we have marked for calcium oxalate in general are $40.42 \%$, shared between $19.14 \%$ of males and $21.27 \%$ of females.

\section{Struvite (Phosphate ammonia magnesium)}

The presence of struvite in urine collected and stored in good conditions can be considered as a specific marker of a urinary tract infection by a microorganism possessing a urease. The urine $\mathrm{pH}$ is above 6.8. Struvite, like most crystalline species, has different facies [20]. From the results obtained (Figure 4,5 ), it is found that the presence of struvite in the urine of patients indicates a urinary tract infection by a microorganism possessing a urease probably linked to the hygiene problem, has poor screening for these infections or insufficient care; the latter is a risk factor for lithogenesis [20]. The presence of struvite is equal between the two sexes and is $6.38 \%$.

\section{Uric acids}

All forms of uric acid crystallize in acidic urine, but the lowest crystallization $\mathrm{pH}$ is observed for uric acid dehydrate ( $\mathrm{pH} 5.25)$. This species therefore often appears as an indirect marker of renal ammonia formation defects when excretion of phosphates is normal, in particular during metabolic syndrome and non-insulin-dependent diabetes which are contexts recognized for their privileged association with uric lithiasis [21]. The results that we have found (Fig. 6, Fig. 7, and Fig. 8) show the frequency of crystalline facies in the urine of lithiasis subjects containing uric acids, dehydrate, anhydrous and in large aggregates. Urinary acidity is the main risk factor for the development of uric lithiasis. Excess animal protein contains in meat, fish, seafood and eggs. Heavy meat eaters are more at risk of kidney stones because animal proteins affect urinary $\mathrm{pH}$ as well as the rate of uric acid excretion, sugary drinks (soft drink, juice) because the fructose they contain may increase your uric acid levels. Also drinking alcohol can increase uric acid levels. Beer is said to have a higher purine content than wine and spirits.

The medical management of uric lithiasis (calculation of pure uric acid and mixed calculation of uric acid and calcium oxalate) therefore requires the maintenance of a diuresis greater than two liters per 24 hours, but also an increase of urine $\mathrm{pH}$, with the objective of a urine $\mathrm{pH}$ between 6.2 and 6.8 for preventive medical treatment, and 7 to 7.2 for dissolution of uric acid stones (pure) in place [22]. In our study, uric acid is very remarkable and ahead of calcium oxalate with a rate of $46.80 \%$, which requires in-depth studies to find the causes of the predominance of uric acid in the urine of lithiasics in the Tissemsilt region.

Conclusion and Prospects for further research. Metabolic explorations begin in practice with the quantification, urinary or plasma, of the main players currently identified in lithogenesis, but the clinical applications of lithogenic risk indices remain marginal. The relatively high rate of recurrent lithiasis illustrates the current limits of preventive measures which can be penalized by the lack of patient attendance but whose reduced effectiveness primarily suggests a lack of knowledge of one or more fundamental determinants of the lithogenic process. The experimental part of our work was devoted to the study and research of crystalline lithiasis species in the polyclinic of Tissemsilt, which initially shows a diversity of crystals in the urine of patients, pure calcium oxalate monohydrate, which was noticed in the majority of the subjects analyzed. There was the presence of whewellite (C1) points to hyperoxaluria. The detection, in crystalluria, of a single crystal of whewellite can therefore be considered as a marker for hyperoxaluria. Weddellite (C2) is generally a simple marker of hypercalciuria which was more common in the urine of subjects analyzed. In fact, the study of crystalluria shows that the presence in abundance of anhydrous uric acid and dihydrated uric acid, uric lithiasis which often forms in acidic urine requires deep investigation to determine the causes in our region. In our study, we observed the presence of struvite crystals which are linked to urinary tract infection according to several bibliographic studies. Our search for crystals in urine allowed us to confirm that despite the simplicity and ease of performing the examination on the urine, the latter remains a very interesting analysis in terms of health. This study has led us to obtain important results.

\section{References}

1. Daudon M. Cristallurie. Néphrologie thérapeutique (Nephrol Ther). 2015; 11(3): 174-90. PMid: 25934324. doi: 10.1016/j.nephro.2015.03.003

2. Renard-Penat R, Ayed A. Diagnostic et bilan des calculs urinaires. Radiologie et imagerie médicale: Génito-urinaire - Gynéco-obstétricale -Mammaire. 2010; 34: 173-183. 
3. Daudon M, Traxer O, Lechevallier E, Saussine C. La lithogenèse. Progrès en urologie. 2008; 18(12): 815-827. PMid: 19033036. doi: 10.1016/j.purol.2008.09.032

4. Daudon M, Traxer O, Jungers P. Lithiase urinaire. 2eme édition, Lavoisier. Medicine sciences (Paris). 2012; 18: 802-816.

5. Oussama A, Kzaiber F, Mernari B, Hilmi A, Semmoud A, Daudon M. Analysis of urinary calculi in adults from the Moroccan Medium Atlas by Fourier transforms infrared spectrophotometry. Prog Urol. 2000; 10: 404-410.

6. Hannache B. La lithiase urinaire: Épidémiologie, rôle des éléments traces et des plantes médicinales. Paris: Université Paris Sud-Paris XI; 2014. 102 p.

7. Werness PG, Bergert JH, Smith LH,. Crystalluria. J Crystal Growth. 1981; 53: 166-81. doi: 10.1016/00220248(81)90063-4

8. Serra AM. Renal lithiasis from a nephrologist's perspective. Port J Nephrol Hypert. 2019; 33(1): 3-6. doi: 10.32932/pjnh.2019.04.002

9. Baumann JM, Affolter B. From crystalluria to kidney stones, some physicochemical aspects of calcium nephrolithiasis. World Journal of Nephrology. 2014; 3(4): 256-267. PMid: 25374820. PMCid: PMC4220359. doi: 10.5527/wjn.v3.i4.256

10. Baumann JM, Casella R. Prevention of Calcium Nephrolithiasis: The Influence of Diuresis on Calcium Oxalate Crystallization in Urine. Advances in Preventive Medicine. 2019; 2019: Article ID 3234867. PMid: 31016047. PMCid: PMC6448328. doi: 10.1155/2019/3234867

11. Tilahun A, Beyene P. Kidney Stone Disease: An Update on Current Concepts. Advances in Urology. 2018; 2018: Article ID 3068365. PMid: 29515627. PMCid: PMC5817324. doi: 10.1155/2018/3068365

12. Daudon M, Traxer O, Lechevallier E, Saussine C. La lithogenèse. Progrès en urologie. 2008; $18(12): 815-827$. PMid: 19033036. doi: 10.1016/j.purol.2008.09.032

13. Elliot JS, Rabinowitz IN. Calcium oxalate Crystalluria: crystal size in urine. J Urol. 1980 Mar; $123(3)$ : $324-7$. PMID: 7359628. doi: 10.1016/s0022-5347(17)55918-2

14. Daudon M, Frochot V. Crystalluria. Clin Chem Lab Med. 2015; 53(Suppl 2): 1479-87. PMID: 26509782. doi: 10.1515/cclm-2015-0860

15. Jouvet P, Priqueler L, Gagnadoux MF, Jan D, Beringer A, Lacaille F, Revillon $Y$, et al. Crystalluria: a clinical useful investigation in children with primary hyperoxalurie post transplantation. Kidney Int. 1998; 53: 1412-6. PMid: 9573560. doi: 10.1046/j.1523-1755.1998.00876.x

16. Paulhac P, Desgrandchamps F, Dumas J-P, Teillac P, Le Duc A, Colombeau P. Rôle de l'uropontine dans la lithogénèse des calculs oxalocalcique. Prog Urol. 2002; 12: 114-117.

17. Kaid-Omar Z, Daudon M, Attar A, Semmoud A, Lacour B, Addou A. Corrélations entre cristalluries et composition des calculs. Progrès en Urologie. 1999; 9: 633-641.

18. Harrache D, Mesri Z, Addou A, Sem Moud A, Lacour B, Daudon M. Analyse des calculs urinaires de l'adulte dans l'Ouest Algérien par spectroscopie infrarouge à transformé de Fourier. Eurobiol. 1997; 31: 69-74.

19. Courbebaisse $M$, Prot-Bertoy $C$, Daudon $M$. Lithiase rénale: des mécanismes au traitement médical : From mechanisms to preventive medical treatment. Néphrologie \& Thérapeutique. 2020; 16(Iss 1): 65-75. PMid: 32122798. doi: 10.1016/j.nephro.2020.01.001

20. Roufosse AH, Landis WJ, Sabine WK, Glimcher MJ. Identification of brushite in newly deposited bone mineral from embryonic chicks. J Ultrastruct Res. 1979; 68: 235-255. doi: 10.1016/S0022-5320(79)90157-6

21. Bensekrane B, Gallart-Mateu D, de La Guardia M, Harrache D. Effets des extraits de noyaux de dattes Phoenix dactylifera L. sur la cristallisation de la brushite dans l'urine totale. Phytothérapie. 2015; 13: 2-13. doi: 10.1007/ s10298-014-0901-3

22. Schillebeeckx C, Vander Eeckt K, Ost D, Van den Branden M, Deconinck S. Kidney Stone Dissolution Therapy in Phosphate Stones. Journal Endourol Case Reports. 2020; 6(1): 45-48. PMid: 32775674. PMCid: PMC7383401. doi: 10.1089/cren.2019.0076

\section{УДК 616.62-003.7-074(651)}

\section{ПОШУК КРИСТАЛІЧНИХ ВИДІВ УРОЛІТІВ} У ПАЦІЄНТІВ РЕГІОНУ ТИССЕМЗІЛТ, АЛЖИР

\section{Бегалія Мохамед, Менді Наджет, Деррі Лінд}

Резюме. Метою дослідження було визначення найбільш розповсюджених різних фрорм кристалів у сечі для подальших заходів щодо попередження виникнення більш тяжких ускладнень кристалурії.

Матеріали і методи. Дослідження було проведено у хворих на уролітіаз вікової групи від 20 до 84 років. Триденні зразки сечі відбирали у різних урологічних відділеннях лікарень Тиссемзілта, Алжир, у період з 06 лютого 2020 року по 21 березня 2020 року. В усіх зразках проводили оцінку кристалурії за видом кристалів, їх кількістю та характером росту. 3 метою коректної інтерпретації отриманих даних, 
в процесі дослідження дотримувалися наступних критеріїв: вибір пацієнтів відповідно до їх метаболічного стану, тривалість та температура зберігання зразків.

Результати і обговорення. Завдяки результатам цього дослідження вдалося охарактеризувати багато типів кристалів, включаючи оксалати кальцію, зокрема моногідрат оксалата кальцію, який розглядається як фрактор ризику утворення каменів. Крім того, наявність кристалів сечової кислоти вказує на специфічні особливості пацієнтів, які залежать від екологічного стану регіону. На додаток до кристалів фоссрату кальцію, отриманих при мікробній інфекції, було виявлено наявність у сечі пацієнтів кристалічних агрегатів, що може в подальшому бути причиною фрормування сечових каменів та розвитку ускладнень, зокрема пієлонефриту. Вважаємо, що мікроскопічне дослідження зразків сечі пацієнта дозволяє обрати терапевтичний алгоритм курації пацієнта за участю урологів, нефрологів, терапевтів.

Висновок. Порівняно високий рівень рецидивів уролітіазу ілюструється сучасними обмеженнями профрілактичних заходів, причиною яких може бути низька явка пацієнтів на прийом до лікаря. Знижена ефективність профілактичних заходів, насамперед, свідчить про недостатнє знання однієї або декількох основних детермінант літогенного процесу лікарями загальної практики та біль вузькими спеціалістами. Результати експериментальної частини даної роботи довели, що у сечі пацієнтів наявні різноманітні кристали, в тому числі, чистого моногідрату оксалату кальцію, що було помічено у більшості досліджуваних. Таким чином, виявлення у сечі пацієнтів кристалів вевеліту може розглядатися як маркер гіпероксалурії. В той же час в веделіт частіше зустрічався в сечі досліджуваних.

Ключові слова: кристали, сечокам'яна хвороба, кристалурія, кристалічна агрегація, сечовивідні шляхи.

Удк 616.62-003.7-074(651)

\section{ПОИСК КРИСТАЛЛИЧЕСКИХ ВИДОВ УРОЛИТОВ}

У ПАЦИЕНТОВ РЕГИОНА ТИССЕМЗИЛТ, АЛЖИР

Бегалия Мохамед, Мэнди Наджет, Дерри Линд

Резюме. Целью исследования было определение наиболее распространенных различных форм кристаллов в моче для дальнейших мероприятий по предупреждению возникновения более тяжелых осложнений кристаллурии.

Материалы и методы. Исследование было проведено у больных уролитиазом возрастной группы от 20 до 84 лет. Трехдневные образцы мочи отбирали в разных урологических отделениях клиник Тиссемзилта, Алжир, в период с 6 февраля 2020 по 21 марта 2020 года. Как лучший метод, оценка кристаллурии использовалась для определения видов кристаллов, их количества и степени увеличения и распространенности. С целью корректной интерпретации полученных данных, в процессе исследования придерживались следующих критериев: выбор пациентов в соответствии с их метаболическим статусом, продолжительность и температура хранения образцов.

Результаты и обсуждение. Благодаря результатам данного исследования удалось охарактеризовать типы кристаллов, включая оксалаты кальция, в частности, моногидрат оксалата кальция, который рассматривается как фрактор риска образования камней. Кроме того, наличие кристаллов мочевой кислоты указывает на специфические особенности пациентов, которые зависят от экологического состояния региона. В дополнение к кристаллам фоссрата кальция, определенных при микробной инфекции, было выявлено наличие кристаллических агрегатов в моче пациентов, что может в дальнейшем быть причиной фрормирования мочевых камней и развития осложнений, в частности пиелонефрита. Считаем, что микроскопическое исследование образцов мочи пациента позволяет выбрать терапевтический алгоритм курации пациента с участием урологов, нефрологов, терапевтов.

Вывод. Сравнительно высокий уровень рецидивов уролитиаза иллюстрируется современными ограничениями профилактических мероприятий, причиной которых может быть низкая явка пациентов на прием к врачу. Сниженная эффективность профилактических мероприятий прежде всего свидетельствует о недостаточном знании одной или нескольких основных детерминант литогенного процесса врачами общей практики и более узкими специалистами. Результаты экспериментальной части данной работы показали, что в моче большинства исследуемых пациентов выявляются различные кристаллы, в том числе чистого моногидрата оксалата кальция. Таким образом, выявление в моче пациентов кристаллов вевеллита может рассматриваться как маркер гипероксалурии. В то же время ведделит чаще встречался в моче испытуемых.

Ключевые слова: кристаллы, мочекаменная болезнь, кристаллурия, кристаллическая агрегация, мочевыводящие пути. 
ORCID and contributionship:

Beghalia Mohamed : ${ }^{\mathrm{C}, \mathrm{D}, \mathrm{F}}$

Mendi Najet : A,B,E

Derri Lind : $A, B, E$

A - Work concept and design, B - Data collection and analysis,

C - Responsibility for statistical analysis, D - Writing the article,

$\mathrm{E}-$ Critical review, F - Final approval of the article

\section{CORRESPONDING AUTHOR}

\section{Beghalia Mohamed}

University Centre of Tissemsilt,

Science and Technology Insitute,

SNV Departement

BP 182, Route de Bougara, Tissemsilt 38000, Algeria

tel: +2130659929818, e-mail: beghaliamohamed@ymail.com

The authors of this study confirm that the research and publication of the results were not associated with any conflicts regarding commercial or financial relations, relations with organizations and/or individuals who may have been related to the study, and interrelations of coauthors of the article. 